\title{
Relationship between Working Period and Knowledge Level to the Prevention of Work Accident through Work Stress on Milled Kettle Workers in Sugar Factory of Rejo Agung Baru Madiun
}

\author{
Caesar Kridha Bagus Prahartiko ${ }^{1}$, FX Ady Soesetijo ${ }^{1,2}$, Ristya Widi Endah Yani ${ }^{1,3}$ \\ ${ }^{1}$ Graduate Student, Magister Program of Public Health Education, Jember University, East Java (Indonesia), \\ ${ }^{2}$ Medical Doctor, Faculty of Dentistry, Jember University, East Java (Indonesia), ${ }^{3}$ Medical Doctor, Faculty of \\ Dentistry, Jember University, East Java (Indonesia)
}

\begin{abstract}
Sugar factory labor was highly vulnerable to get work accident in work place. The objective of this research was to identify the relation between working period and knowledge level to the prevention of work accident through variable of work stress on mill and kettle workers. This research was quantitative in analytical observational method and cross sectional design. Total sample of research were 115 workers in the sugar mill and kettle at sugar factory of Rejo Agung Baru Madiun through total sampling. The research data was tested in SEM (Structural Equation Model) method by exerting instrument of Stata 13 to analyze the data. Based on the finding of research, on the sig value of working period 0.006 and sig value of knowledge level 0.023 , it referred the relation in variable of working period through work stress, while no relation in variable of knowledge level through work stress to the prevention of work accident. Thus, it required to more stimulation to the knowledge level and more support to the workers in order to minimize their work stress.
\end{abstract}

Keywords: K3, Sugar Factory, Milled Kettle, Stress, Work Accident.

\section{Introduction}

Work accident is an unpredictable and unexpected situation by all workers which might occur, it is often unpredictable and cause to time and property loss, or even victim in the working world. This work accident is caused by a contact between energy sources as mechanical, chemical, physical, and kinetic which affect to injury on human, environment, or working tools. ISO 14001, 2004 has asserted that the work accident is defined as an incident which occurs on labor and causes to occupational illness, injury, or even death ${ }^{[7]}$.

Prevention of work accident can be implemented through strategies of work accident prevention which are addresses to working machine, environment, equipment and supplies as well as human factor. Environmental condition is needed to fulfill standards or safety and security, proper condition of work place according to the standard of work safety until the planning which needs extra attention to fulfill the safety standard ${ }^{[10]}$. The work accident also impacts to significant expense for the organization, employee, and even society in overall. The expense is varied based on lowest level up to the highest level, with the duration of sick leave because of work accident. The long duration of sick leave will impact to the organization, since the labor or employee will be less productive along that period of time. The sick leave of employee means that the organization must keep paying the salary along the leave period of employee (it appears to the expense proportionally over the work-days left). The alternative which can be implemented during employee's leave is to look for the substitute as the parttime employee. However, this part-time employee must also be paid by the organization. This also might impact to the higher cost of expense in an organization, if the work accident is not minimized as good as possible ${ }^{[3]}$.

Working period is defined as a duration of employee to exert effort and time to the factory or organization as well as produce absorption from many kinds of 
human activity. The longer working period will make the employee have more experiences and be able to help the factory or organization to produce output and better performance. Working period can build skill of employee, so the work will be performed well. Therefore, the longer working period will identify better working skill of employee ${ }^{[9]}$.

Knowledge is a result of knowing towards a particular object through five sense (eye, nose, ear, and other senses) or a production of human sensing. Naturally human sense produces knowledge which is very affected by the intensity of attention and perception on certain object. It mainly gotten through sense of hearing and sight ${ }^{[6]}$.

Knowledge is mental components which has been resulted from whole process physically or connately which is derived from individual experience ${ }^{[8]}$. It is divided into several aspects, as 1) Know, as the reminder of subject which has been learned in the past. This level is considered as recall stage or re-remember on stimulus received. Thus, know is the lowest stage in the knowledge aspect, 2) Comprehension, as being able to explain well about particular object which is known as well as to interpret subject properly. It is also about to explain, mention, conclude, estimate the object which is being learned at that time, 3) Application, it aims to exert the subject as things that have been learned in the real situation or condition, 4) Analysis, the activity of information sorting into many parts or activities which examines and attempts to understand information, 5) Synthesis, an ability to put and relate parts within an overall form, or it is simply explained as the ability to arrange new formulation from some existing formulation, 6) Evaluation, where the individual has ability to value on particular object ${ }^{[1]}$. There are factors which can influence individual knowledge: age, educational level, working experience, up to the information which is obtained by the individual ${ }^{[5]}$.

Work stress is a state of stress which impacts individual to have unbalanced psychological and physical condition that will influence the process of thinking, emotion, and condition of employee. The individual who often worries and feel nervous indicates signals of stressful individual, as a result, it will make the individual more aggressive, get angry frequently, unrelaxed condition, until uncooperative behavior towards the surrounding environment ${ }^{[4]}$. Generally, the phase of mild stress does not damage the individual or employee from their physiological aspect. The mild stress on individual in their daily life will make the employee to be more alert and not cause to disease, next, the phase of severe stress, where the duration of severe stress is longer than the mild one. It can be in week or even years, thus, the severe stress can danger individual or employee. The example of severe stress is inharmonious relationship with family or partner of life, chronic disease, until financial difficulty. Aboutresponses which emerge from this severe stress are indigestion, asphyxia, tremor, and often feel confused or panic ${ }^{[11]}$.

However, the stress can result positive things in the end, as calmness, high motivation, good perception, and high energy. Those responses also impact well to the employee as long as the stress management can be managed well, then, the task or work is finished well and relation with the surrounding goes well. On the other hand, if the individual response during work stress is negative, it will impact badly as decreased motivation, easy to get angry or offended, work absence, apathetic, easy to make mistake during working, and inability to take decision. Those negative impacts are very influential to the individual and their work environment. They are caused by the individual inability to manage the stress, so it cause problems among employees or even unfinished works ${ }^{[12]}$.

The research is conducted on the milled kettle workers in sugar Factory of Rejo Agung Baru Madiun.

\section{Method}

This research was included into observational analytical research which exerted observational analytical method and aimed to identify the relation between knowledge level and working period to the prevention of work accident through variable of work stress. The researchers employed cross sectional research design on the total respondents 115 milled kettle workers in Sugar Factory of Rejo Agung Baru Madiun by using questionnaire sheets which have been valid and reliable to the variables of working period, knowledge level, work stress as well as prevention of work accident in questionnaire as the research instrument. Each variable questionnaire was consisted of 10 items for the knowledge level, 11 items for the work stress and 12 items for the prevention of work accident, while the working period was identified from standard of working period which has been determined by the organization. The research data was analyzed in SEM (Structural Equation Model) by exerting instrument of Stata 13. 


\section{Research Findings}

\section{Univariate Analysis}

a. Working Period: Variable of working period was consisted of two categories: long working period and new working period. The $1^{\text {st }}$ table would define the working period of milled kettle labor from the total respondents 103 workers where particularly 71 workers have long working period (62\%), while 44 workers have new working period (38\%).

$1^{\text {st }}$ table of Working Period:

\begin{tabular}{|l|c|c|}
\hline Working Period & Respondent (n) & Percentage \% \\
\hline Long & 71 & 62 \\
\hline New & 44 & 38 \\
\hline Total & 115 & 100 \\
\hline
\end{tabular}

b. Knowledge Level: Variable of knowledge level was divided into two categories, good and poor category. $2^{\text {nd }}$ table would illustrate data distribution which gathered from 115 respondents, that 67 workers have good educational level (58\%), while 48 workers have poor educational level (42\%).

$2^{\text {nd }}$ table of Knowledge Level:

\begin{tabular}{|l|c|c|}
\hline Knowledge Level & Respondent (n) & Percentage \% \\
\hline Good & 67 & 58 \\
\hline Poor & 48 & 42 \\
\hline Total & 115 & 100 \\
\hline
\end{tabular}

c. Work Stress: Variable of work stress was divided into two categories, as mild and severe stress, $3^{\text {rd }}$ table would explain that from the total 115 respondents, 65 workers have mild work stress $(57 \%)$, while 50 workers have severe work stress $(50 \%)$.

\section{$3^{\text {rd }}$ Work Stress:}

\begin{tabular}{|l|c|c|}
\hline Work Stress & Respondent (n) & Percentage \% \\
\hline Mild & 65 & 57 \\
\hline Severe & 50 & 43 \\
\hline Total & 115 & 100 \\
\hline
\end{tabular}

d. Prevention of work Accident: Prevention of work accident on milled and kettle workers in Sugar Factory of Rejo Agung Baru Madiun illustrated that workers section have prevented towards work accident in about 63 respondents (55\%), while 52 respondents $(45 \%)$ have not been good in preventing work accident as it was illustrated on the following table:

\section{$4^{\text {th }}$ table Prevention of Work Accident:}

\begin{tabular}{|c|c|c|}
\hline $\begin{array}{c}\text { Prevention } \\
\text { of Work } \\
\text { Accident }\end{array}$ & Respondent (n) & $\begin{array}{c}\text { Percentage } \\
\text { \% }\end{array}$ \\
\hline Good & 63 & 55 \\
\hline Not good & 52 & 45 \\
\hline Total & 115 & 100 \\
\hline
\end{tabular}

2. Multivariate Analysis: Path analysis test was aimed to identify indirect relation between independent variable and dependent variable through intervening variable. Further, path analysis in this research exerted pat analysis in logistic regression base. The software of Stata 13 was used to analyze the research data in this research, it resulted:

\begin{tabular}{|l|l|c|c|c|c|c|c|c|}
\hline \multicolumn{2}{|l}{ Variable } & Log odd & Coefficient & S.E & Z & P Value & \multicolumn{2}{|c|}{ CI 95\% } \\
\hline \multirow{2}{*}{ Work Stress } & BWorking Period & -1.2 & -1.157 & 0.425 & -2.72 & 0.006 & -1.99 & -0.32 \\
\cline { 2 - 9 } & BKnowledge Level & -0.76 & -0.762 & 0.431 & -1.77 & 0.077 & -1.61 & 0.08 \\
\hline Prevention of Work Accident & BWork Stress & 0.87 & 0.875 & 0.384 & 2.28 & 0.023 & 0.123 & 1.63 \\
\hline
\end{tabular}

$5^{\text {th }}$ table Table of Estimation Result: Negative relation between working period and work stress incident was indicated by the log odd coefficient in each score unit of working period variable that could reduce work stress in about 1.2 unit, and significant relation statistically (CI $95 \%=-1.99$ up to $-0.32 ; p$ value $=0,006)$. Relation between knowledge level and work stress incident was negative. Moreover, the log odd coefficient in each unit of knowledge could reduce the work stress in about 0.76 unit, and did not show any relation statistically (CI 95\% $=-1.61$ up to $0.08 ; p$ value $=0.077)$. It referred to the positive relation between work stress and prevention of work accident. Log odd coefficient in each score unit of work stress could improve prevention of work accident in about 0.087 unit, and have significant relation statistically $(\mathrm{CI} 95 \%=0.123$ up to $1.63 ; \mathrm{p}$ value $=0.023)$. About 
indirect relation of working period through variable of work stress to the prevention of work accident resulted value -1.044 . This inidrect relation from the variable of working period -1.044 , where the path analysis on direct relation value between working period and work stress -1.2. Whereas, the knowledge level and prevention of work accident through work stress -0.66 from the calculation result $(-0.76) \times(0.87)=-0.66$. It was not indicated to significant relation statistically on the level of knowledge, due to the $p$ value of knowledge level was higher than $p$ value $0.077>0.05$.

Direct relation was the relation between independent variable and dependent variable except through intervening variable. The relation of total working period in prevention of work accident -1.044 through formula $(-1.2) \times(0.87)+0=-1.044$, while for the knowledge level $(-0.76) \times(0.87)+0=-0.66$. Value score is 0 was derived because of no indication of direct relation between variable of working period and knowledge level to the prevention of work accident.

\section{Discussion}

Work stress and working period resulted to negative relation to the prevention of work accident. The result of path analysis showed that on log odd coefficient in each score unit of working period was able to decrease work stress of employee in about 1.2 unit, where the long period of working could reduce the severe level of work stress, then, workers who have been in the long working period could minimize possibility of severe stress than workers in new working period. Globally, either new working period or long working period could rise to work stress, surrounding environment was also able to be the trigger of work stress from the physical and social environment condition, as well as work target demand of the factory or organization. Monotonous activity in working and age factor due to the long period of work could impact tired condition that raised to work stress ${ }^{[2]}$. The longer experience indicated that the workers have undergone critical periods during working in the factory or organization, which affected the labor to be more calm during working. Therefore, the prevention of work accident was better and profitable for both parties.

Knowledge level and work stress was not related to prevention of work accident. Log odd coefficient in each score unite of knowledge level could reduce the work stress in about 0.76 unit. The worker who have good knowledge level could decrease severe stress level than worker who have poor knowledge level, but it did not indicate to significant relation statistically in this research, since the $\mathrm{p}$ value of knowledge level (0.077) was higher than the $p$ value (0.05). Knowledge level in this research was not related to work stress which referred that knowledge level should pass variable of attitude. Attitude could determine whether decision should be taken or not. In addition to knowledge level, if on the average, worker have good knowledge level but bad attitude, the attempt of work accident prevention would not be appropriate to purpose. Intervening variable in this research is work stress which no relation with prevention of work accident. Knowledge level did not have any relation, because it was possible that knowledge level of workers was only to know, but did not reach to the evaluation stage where workers should understand or comprehend about the prevention of work accident.

\section{Conclusions}

Working period in this research showed relation to prevention of work accident through variable of work stress, while knowledge level did not show to any relation to prevention of work accident through variable of work stress on milled and kettle workers in Sugar Factory of Rejo Agung Baru Madiun. Next, the work stress as intervening variable resulted about relation to the prevention of work accident on milled and kettle workers in Sugar Factory of Rejo Agung Baru Madiun. Furthermore, researchers suggested that the workers with long working period should share their experience to new workers and remind them to keep focusing on how to minimize about possibility of work accident. Workers were expected to follow acceleration system to equalize the educational level. Since, the higher level of education would result to more knowledge. Stress management was also needed for the workers, so the work stress and work accident could be minimized.

\section{Conflict of Interest: Nothing}

\section{Source of Funding: Self}

Ethical Clearance: This research has undergone ethical test in ethics commission of health research of Faculty of Dentistry, University of Jember in this following registration number 416/UN25.8/KEPK/ DL/2019. 


\section{References}

1. Azwar,S. Sikap Manusia:Teori dan Pengukurannya. Yogyakarta: Pustaka Pelajar. 2013. p. 22

2. Barkhoudari, A., Malmir, B., \& Malakoutikhah, M. An Analysis of Individual and Social Factors Affecting Occupational Accidents. Safety and Health at Work. 2019. p.3-5https://doi. org/10.1016/j.shaw.2019.01.002

3. Fontaneda, I., \& Ritzel, D. Gender differences in lost work days due to occupational accidents. Safety Science. 2018. p.3.https://doi.org/10.1016/j. ssci. 2018.12.027

4. Hasibuan, M. Manajemen Sumber Daya Manusia. Edisi Revisi . Jakarta: Bumi Aksara. 2012. p. 33

5. Notoatmodjo, S. Promosi Kesehatan dan Perilaku Kesehatan. Jakarta: Rineka Cipta. 2012. p. 45

6. Notoatmodjo, S. Ilmu Perilaku Kesehatan. Jakarta: Rineka Cipta. 2014. p.62
7. Prayitno, H.Keselamatan dan Kesehatan Kerja (K3) pada Standard Operasional Prosedur (SOP). Ponorogo: Forum Ilmiah Kesehatan (Forikes). 2016. p.33.

8. Reber, S., \& Reber, S. Kamus Psikologi. Yogyakarta: Pustaka Pelajar. 2010. p.201

9. Rudiansyah. Manajemen Kepegawaian. Yogyakarta: Kanisius. 2014. p.44

10. Suma'mur. Hygiene Perusahaan dan kesehatan kerja (HIPERKES). Jakarta: Sagung Seto. 2009. p.112.

11. Rasmun. Stres, Koping dan Adaptasi : Teori dan Pohon Masalah Keperawatan. Jakarta: CV Sagung Seto. 2009. p.113.

12. John, M., Robert, K., Michael, T., \& Ivancevich. Perilaku dan Manajemen Organisasi: Edisi Ketujuh. Jakarta: Erlangga. 2009. p.75. 